Check for updates

Cite this: RSC Adv., 2017, 7, 56764

Received 7th December 2017

Accepted 11th December 2017

DOI: 10.1039/c7ra13120h

rsc.li/rsc-advances

\section{Four-component synthesis of polyhydroquinolines under catalyst- and solvent-free conventional heating conditions: mechanistic studies $\dagger$}

\author{
Pipattra Mayurachayakul, ${ }^{a}$ Wanchai Pluempanupat, ${ }^{b}$ Choladda Srisuwannaket $^{a}$ \\ and Oraphin Chantarasriwong (iD *a
}

A convenient and environmentally friendly procedure for the synthesis of polyhydroquinolines via a onepot, four component condensation of different aromatic aldehydes with dimedone, ethyl acetoacetate and ammonium acetate has been developed. Upon heating at $100{ }^{\circ} \mathrm{C}$, the desired products were produced in good to excellent yields with short reaction times under catalyst- and solvent-free conditions. Mechanistic studies indicated that two possible pathways can be accounted for the fourcomponent synthesis of polyhydroquinolines. Unexpectedly, the first involves a nucleophilic attack of a Michael intermediate by an enamine, followed by a retro-aldol-type reaction and a six-electron ring cyclization. The second, which was previously proposed, involves a Michael addition of a Knoevenagel intermediate and an enamine.

\section{Introduction}

1,4-Dihydropyridines have a documented value in the pharmaceutical industry as calcium channel blockers prescribed for the treatment of cardiovascular diseases, ${ }^{1}$ including hypertension, ${ }^{2}$ angina $^{3}$ and supraventricular arrhythmias. ${ }^{4}$ They have also exhibited potent antiplasmodial, ${ }^{5}$ antibacterial, ${ }^{6}$ antiproliferative, ${ }^{7}$ antimalarial, ${ }^{8}$ antitubercular, ${ }^{9}$ anticancer ${ }^{10}$ and anti-HIV-1 protease activities. ${ }^{11}$ Polyhydroquinolines, a related class of 1,4-dihydropyridines, have been shown to have remarkable pharmaceutical properties, such as antibacterial, antimalarial, ${ }^{12}$ antitubercular, ${ }^{12 b}$ and antiproliferative ${ }^{13}$ activities. Among them, compound $\mathbf{P 1}$ is a cardiomyogenic agent candidate for the inhibition of TGF $\beta$ signaling. ${ }^{14}$ Studies on ovariectomized rodent models have indicated that polyhydroquinoline-coumarin hybrid $\mathbf{P 2}$ is a potent osteoblastic bone formation promoter in vitro and prevents ovariectomyinduced bone loss in vivo. ${ }^{15} \mathrm{~A}$ recent study reported that longchain fatty acid polyhydroquinoline derivatives, such as P3, display strong activity against the glioma cell line (Fig. 1). ${ }^{13}$

Aside from the impressive biological and pharmaceutical properties of 1,4-dihydropyridines and related compounds,

${ }^{a}$ Organic Synthesis, Electrochemistry \& Natural Product Research Unit, Department of Chemistry, Faculty of Science, King Mongkut's University of Technology Thonburi, 126 Pracha Uthit Rd., Bang Mod, Thung Khru, Bangkok 10140, Thailand. E-mail: oraphin. cha@kmutt.ac.th

${ }^{b}$ Department of Chemistry and Center of Excellence for Innovation in Chemistry, Faculty of Science, Special Research Unit for Advanced Magnetic Resonance, Kasetsart University, Bangkok 10900, Thailand

$\dagger$ Electronic supplementary information (ESI) available. See DOI: 10.1039/c7ra13120h many methods for their syntheses have been reported. Multicomponent reactions are among the most important tools since they can produce large amounts of target products in economically and environmentally acceptable ways. 1,4-Dihydropyridines were first synthesized by the Hantzsch reaction, which involves a multicomponent condensation of aldehydes with ethyl acetoacetate and ammonia in acetic acid or refluxing ethanol. ${ }^{16}$ Multicomponent syntheses have been used for the preparation of polyhydroquinolines, which mostly rely on the use of catalysts, such as Lewis or Brønsted acids, ${ }^{17}$ organocatalysts, ${ }^{18}$ biocatalysts, ${ }^{19}$ ionic liquids ${ }^{20}$ and nanoparticles. ${ }^{21}$ Solvent- and catalyst-free conditions ${ }^{22}$ have also been developed for these reactions with the assistance of microwaves, ${ }^{23}$ solar thermal energy, ${ }^{24}$ and grinding. ${ }^{25}$ In addition, solvent-free conditions were used for the two-step synthesis of unsymmetrical 1,4-dihydropyridines that includes the reaction of aromatic aldehydes with acetoacetate esters in the presence of a catalytic amount of piperidine and acetic acid, followed by the reaction of the resulting benzylidenes and methyl-3-aminocrotonate

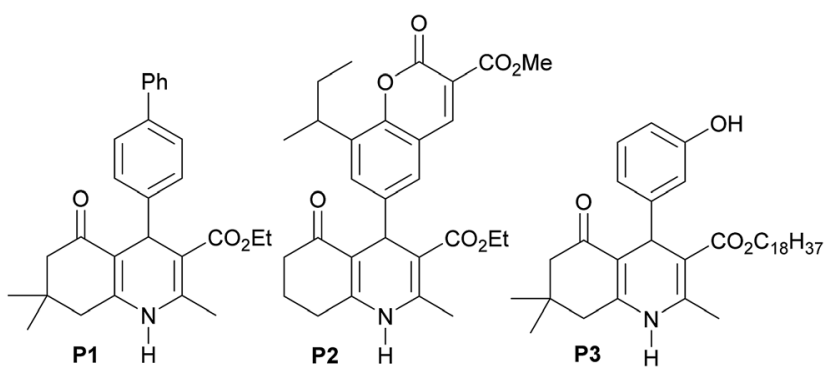

Fig. 1 Representative bioactive polyhydroquinolines. 


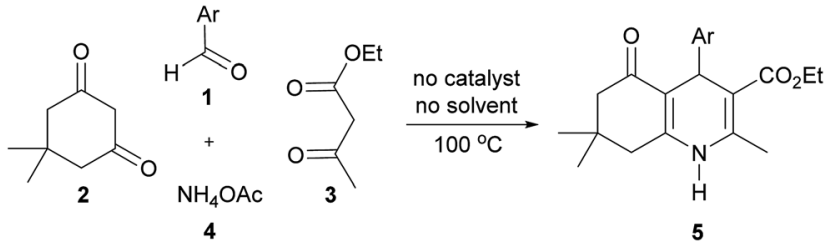

Scheme 1 Four-component synthesis of polyhydroquinolines 5.

with small additional amounts of acetic acid. ${ }^{26}$ Although these methodologies represent individual advantages, some are associated with a few drawbacks, such as the use of organic solvents, high catalyst loadings, tedious multi-step synthesis, long reaction times and inconvenient apparatuses. Therefore, a green and practical protocol is still needed. To the best of our knowledge, there is no report exploring a one-pot fourcomponent synthesis of polyhydroquinolines under catalystand solvent-free conventional heating. Moreover, an experimental proof of the reaction mechanism has never been addressed. Herein, we present a green and efficient one-pot method for the catalyst- and solvent-free synthesis of polyhydroquinolines via a four-component reaction under conventional heating at $100{ }^{\circ} \mathrm{C}$ (Scheme 1). In addition, we explore mechanistic studies of the reactions.

\section{Results and discussion}

To optimize the reaction conditions for the solvent- and catalyst-free synthesis of polyhydroquinolines, the effect of reaction temperatures was examined using benzaldehyde (1a), dimedone (2), ethyl acetoacetate (3) and ammonium acetate (4) as model substrates (Table 1 ).

When the reaction was carried out at room temperature for $5 \mathrm{~min}$, the reaction mixture was in the liquid state, resulting in

Table 1 Effect of reaction temperatures on the synthesis of polyhydroquinoline $5 a^{a, b}$

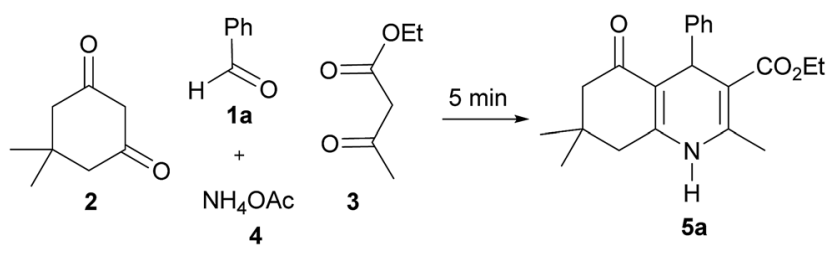

\begin{tabular}{lll}
\hline Entry & Temperature $\left({ }^{\circ} \mathrm{C}\right)$ & Yield 5a $(\%)$ \\
\hline 1 & rt & 30 \\
2 & 50 & 42 \\
3 & 75 & 52 \\
4 & 100 & 66 \\
5 & 125 & 62 \\
6 & 150 & 56
\end{tabular}

${ }^{a}$ Reaction conditions: $1 \mathrm{a}(1 \mathrm{mmol}), 2$ ( $\left.1 \mathrm{mmol}\right), 3$ ( $\left.1 \mathrm{mmol}\right)$ and 4 (1.5 mmol) under catalyst- and solvent-free conditions, 5 min. ${ }^{b}$ Isolated yield. a low yield of desired product 5a (30\%, entry 1). Increasing the reaction temperature to 50,75 and $100{ }^{\circ} \mathrm{C}$, the yields of product $5 \mathbf{a}$ were increased to 42,52 and $66 \%$, respectively (entries $2-4$ ). At these temperatures, solid material was gradually observed indicating the formation of the desired product. However, the product yields decreased when the reaction temperature was raised to 125 and $150{ }^{\circ} \mathrm{C}\left(56-62 \%\right.$, entries 5 and 6). Thus, $100{ }^{\circ} \mathrm{C}$ was determined to be the optimum temperature for the synthesis of polyhydroquinolines under solvent- and catalystfree conditions.

The condensation of various aromatic aldehydes (1) with dimedone (2), ethyl acetoacetate (3) and ammonium acetate (4) under solvent- and catalyst-free conditions at $100{ }^{\circ} \mathrm{C}$ was then explored to investigate the scope and limitations of the method (Table 2).

The reactions of all the aromatic aldehydes gave the desired products in good to excellent yields in only 5-60 min. It should be mentioned that some starting aldehydes do not melt at low temperatures. Along this line, the high temperature $\left(100{ }^{\circ} \mathrm{C}\right)$ is needed for the formation of simple or eutectic melts under solvent-free conditions. ${ }^{27}$ The reaction of benzaldehyde gave a lower yield of product than that of aromatic aldehydes bearing a strong electron-withdrawing group $\left(-\mathrm{NO}_{2}\right)$ or a halogen atom $(-\mathrm{Cl}$ and $-\mathrm{Br})$ at the para-position (5a vs. 5b, 5c and 5d, $73 \%$ vs. 92-99\%). The excellent yields were obtained from the reactions of aromatic aldehydes containing a strong electron-donating substituent (-OMe and $-\mathrm{NEt}_{2}$ ), and the corresponding products 5e and $5 \mathbf{f}$ were provided in $5 \mathrm{~min}(89-91 \%)$. Meanwhile, the reactions of 4-tert-butylbenzaldehyde and 4-phenylbenzaldehyde led to the corresponding products $5 \mathbf{g}$ and $5 \mathbf{h}$ in good yields ( $76 \%$ and $62 \%$, respectively). To improve the yields of products $5 \mathrm{~g}$ and $5 \mathrm{~h}$, the reactions were heated for $40-45 \mathrm{~min}$; however, the yield of product $\mathbf{5 h}$ was only increased $(75 \%)$. The use of 3-nitrobenzaldehyde, which contains a strong electronwithdrawing group at the meta-position, provided a lower product yield than that of 3-hydroxybenzaldehyde, containing a strong electron-donating group (5i and $5 \mathbf{j}, 60 \%$ vs. 91\%). Gratifyingly, the yield of product $\mathbf{5 i}$ could be improved by heating the reaction for $60 \mathrm{~min}(80 \%)$. In the case of a substituent at ortho-position, such as 2-chlorobenzaldehyde, it had a little effect on the product yield. Nevertheless, the yield of product $5 \mathbf{k}$ was improved by prolonged heating of the reaction mixture for $10 \mathrm{~min}(70 \%)$. In contrast, the reaction of 2methoxybenzadehyde was much faster and afforded the corresponding product $\mathbf{5 1}$ in high yield within 5 min (79\%). Fortunately, the excellent yield of product $5 \mathbf{l}$ was achieved by increasing the reaction time to $15 \mathrm{~min}(90 \%)$.

Aromatic aldehydes bearing two substituents were also performed. The reaction of 3,4-dichlorobenzaldehyde and 3,5dibromobenzaldehyde proceeded well and gave the corresponding products $\mathbf{5 m}$ and $\mathbf{5 n}$ in good yields in $10 \mathrm{~min}(85 \%$ and $72 \%$, respectively). Interestingly, this method proved to be very useful for a salicylaldehyde derivative, such as 2-hydroxy-5nitrobenzaldehyde, which generated the corresponding product 50 in nearly quantitative yields in $5 \mathrm{~min}$ (96\%). Polyhydroquinolines 5a-5m are known and their spectroscopic data were found to be identical to those reported in the literature (see 
Table 2 Effect of various aromatic aldehydes on the synthesis of polyhydroquinolines $5^{a, b}$<smiles>CCOC(=O)CC(C)=O</smiles><smiles>[B]N1C(C)=C(C(=O)OCC)C(c2ccccc2)C2=C1CC(C)(C)CC2=O</smiles>

$5 \mathrm{~min}, 66 \%$ $10 \mathrm{~min}, 73 \%$<smiles>CCOC(=O)C1=C(C)N(C)C2=C(C(=O)CC(C)(C)C2)C1c1ccc(N(CC)CC)cc1</smiles><smiles>CCOC(=O)C1=C(C)N(Cc2ccccc2)C2=C(C(=O)CC(C)(C)C2)C1c1ccccc1Cl</smiles><smiles>CCOC(=O)C1=C(C)NC2=C(C(=O)CC(C)(C)C2)C1c1ccc([N+](=O)[O-])cc1</smiles>

$10 \min , 98 \%$<smiles>CCOC(=O)C1=C(C)N(C)C2=C(C(=O)CC(C)(C)C2)C1c1ccc(C(C)(C)C)cc1</smiles><smiles>CCOC1=C(C)NC2=C(C(=O)CC(C)(C)C2)C1c1ccccc1OC</smiles><smiles>CCOC(=O)C1=C(C)NC2=C(C(=O)CC(C)(C)C2)C1c1ccc(Cl)cc1</smiles>

$10 \min , 92 \%$<smiles>CCOC(=O)C1=C(C)N(N)C2=C(C(=O)CC(C)(C)C2)C1c1ccc(-c2ccccc2)cc1</smiles><smiles>CCOC(=O)C1=C(C)NNC2=C(C(=O)CC(C)(C)C2)C1c1ccc(Cl)c(Cl)c1</smiles>

$10 \min , 85 \%$<smiles>CCOC(=O)C1=C(C)NC2=C(C(=O)CC(C)(C)C2)C1c1ccc(Br)cc1</smiles>

$10 \min , 99 \%$<smiles>CCOC(=O)C1=C(C)N(C)C2=C(C(=O)CC(C)(C)C2)C1c1cccc([N+](=O)[O-])c1</smiles><smiles>CCOC(=O)C1=C(C)NC2=C(C(=O)CC(C)(C)C2)C1c1cc(Br)cc(Br)c1</smiles>

$10 \min , 72 \%$<smiles>CCOC(=O)C1=C(C)NC2=C(C(=O)CC(C)(C)C2)C1c1ccc(OC)cc1</smiles>

$5 \mathrm{~min}, 91 \%$<smiles>CCOC(=O)C1=C(C)NC2=C(C(=O)CC(C)(C)C2)C1c1cccc(O)c1</smiles><smiles>CCOC1=C(C)NC2=C(C(=O)CC(C)(C)C2)C1c1cc([N+](=O)[O-])ccc1O</smiles>

${ }^{a}$ Reaction condition: 1 (1 mmol), $2(1 \mathrm{mmol}), 3(1 \mathrm{mmol})$ and $4(1.5 \mathrm{mmol})$ under catalyst- and solvent-free condition at $100{ }^{\circ} \mathrm{C} .{ }^{b}$ Isolated yield.

ESI $\dagger$ ). Polyhydroquinolines $5 n$ and 50 were synthesized for the first time in this report and their identities were fully characterized by spectroscopic methods.

A reaction mechanism for multicomponent reactions of polyhydroquinolines has been proposed to occur via a Michael addition of two intermediates $\mathbf{K 1}$ and E1 that are derived from a Knoevenagel condensation of aldehyde (1) with dimedone (2), and an enamine reaction of ethyl acetoacetate (3) with ammonium acetate (4), respectively (Scheme 2). ${ }^{\mathbf{1 7 f , 1 8 , 2 0 a , 2 0 e , 2 0 f , 2 1 b , 2 1 k}}$ However, no experimental evidence of the mechanism has yet been discovered.

In an attempt to isolate the intermediates formed in the early stages of the reaction, benzaldehyde (1a) was treated with dimedone (2), ethyl acetoacetate (3) and ammonium acetate (4) under solvent-free condition at $100{ }^{\circ} \mathrm{C}$ for $1 \mathrm{~min}$, resulting in the isolation of polyhydroquinoline $5 \mathrm{a}$ in $30 \%$ yield along with two adducts M1 (45\%) and K2 (7\%) (see M1 and K2 structures in

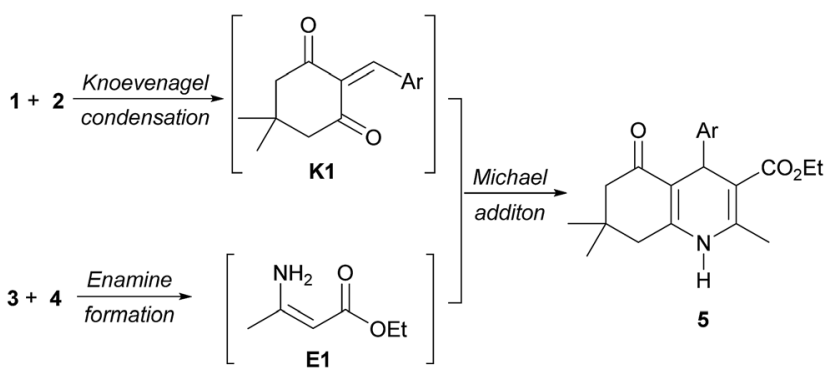

Scheme 2 Previously proposed intermediates. 


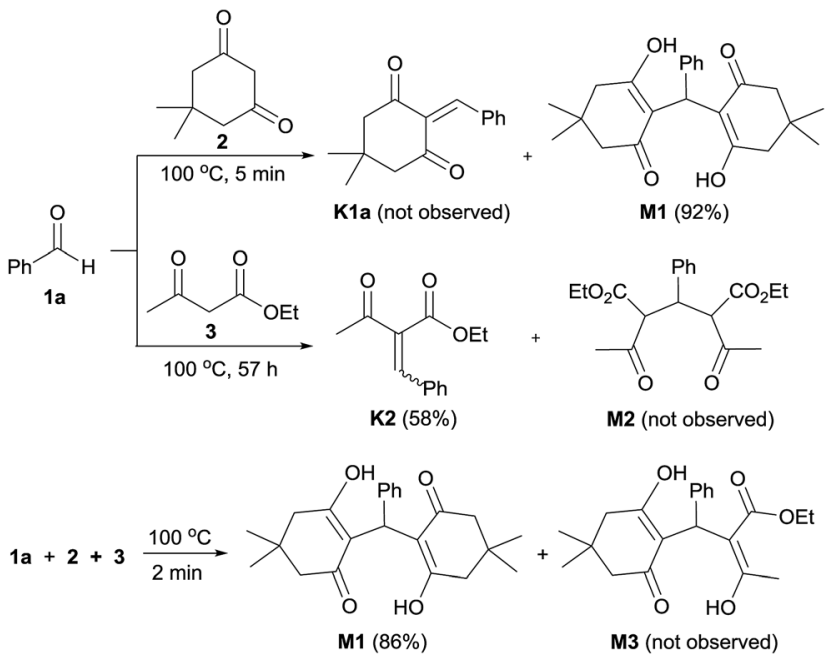

Scheme 3 Reaction of benzaldehyde and 1,3-diketone.

Scheme 3). The ${ }^{1} \mathrm{H}$ NMR spectrum of adduct M1 reveals the characteristic signals at $\delta 11.89$ (br s, OH) and $\delta 5.52(\mathrm{~s}, \mathrm{Ph}-\mathrm{CH})$, suggesting that this adduct is a Michael intermediate derived from the Michael addition of Knoevenagel intermediate K1a (see structure in Scheme 3) and dimedone (2). Whereas the ${ }^{1} \mathrm{H}$ NMR spectrum of adduct $\mathbf{K} 2$ shows the two singlets of a vinylic proton at $\delta 7.55$ and $\delta 7.65$, indicating that this adduct is a mixture of $Z$ and $E$ isomers (ca. 1:2 ratio) of Knoevenagel intermediate formed by the condensation of benzaldehyde (1a) and ethyl acetoacetate (3) (see ESI† for characterization data). These preliminary results suggested that Michael adduct M1 and Knoevenagel adduct $\mathbf{K} \mathbf{2}$ might account for the mechanistic pathway as a key intermediate. To test this hypothesis, a set of two-component reactions was initially performed to prepare the Michael and Knoevenagel intermediates (Scheme 3). Under the catalyst- and solvent-free conditions at $100{ }^{\circ} \mathrm{C}$, only the single Michael adduct M1 was obtained in $92 \%$ yield within 5 min from an equimolar mixture of benzaldehyde (1a) and dimedone (2). Varying different temperatures and reaction times for the preparation of Knoevenagel adduct K1a met with failure. In all these cases the Michael adduct M1 was only observed. In contrast, the equimolar reaction of benzaldehyde (1a) and ethyl acetoacetate (3) afforded only Knoevenagel adduct $\mathbf{K 2}$ in $58 \%$ yield after 57 hours. A competitive three-component reaction between benzaldehyde (1a), dimedone (2) and ethyl acetoacetate (3) was also carried out under the same condition (Scheme 3). As unexpected, only Michael adduct M1 was obtained in $86 \%$ yield within 2 min without the observation of adduct M3. These findings suggest that dimedone is a much better nucleophile for electrophiles, such as benzaldehyde, in comparison to ethyl acetoacetate. Indeed, the Knoevenagel intermediate K1a is much more reactive toward a Michael addition than the Knoevenagel intermediate $\mathbf{K} 2$.

Recently, Chung and co-workers reported that a nucleophilic attack of an aromatic amine on the Michael adduct intermediate, followed by a six-electron ring cyclization could lead the formation of tetrahydroacridinones. ${ }^{28}$ Inspired by their work, the mixture of Michael adduct M1 and enamine E1, prepared from the reaction of ethyl acetoacetate (3) and ammonium

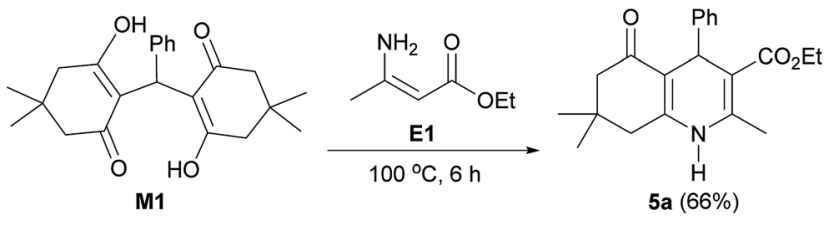

Scheme 4 Reaction of Michael adduct M1 and enamine E1.

acetate (4), was heated under the solvent-free condition (Scheme 4). This reaction successfully proceeded to afford polyhydroquinoline 5a in $66 \%$ yield. This finding provides insight into the unexpected mechanism for the four-component reaction of the polyhydroquinolines that involves the Michael adduct $\mathbf{M 1}$ as a key intermediate.

In addition, the Knoevenagel adduct $\mathbf{K} 2$ was treated with enamine E2, obtained from dimedone (2) and ammonium acetate (4), furnishing polyhydroquinoline $5 \mathrm{a}$ in $62 \%$ yield (Scheme 5). This result confirmed that the Knoevenagel adduct K2 is another key intermediate in the reaction. To investigate a role of acetic acid in the reaction, an equivalent of acetic acid was therefore added. It was found that the desired product $\mathbf{5 a}$ was slightly increased, indicating that this reagent does not significantly serve as a catalyst under solvent-free condition at $100{ }^{\circ} \mathrm{C}$. Based on all experimental results, the four-component reaction for the solvent-free synthesis of polyhydroquinolines under conventional heating at $100{ }^{\circ} \mathrm{C}$ involves two possible mechanistic pathways (Scheme 6). The first pathway involves Knoevenagel condensation of benzaldehyde (1a) and dimedone (2), giving reactive Knoevenagel intermediate K1a. This intermediate immediately reacts with another molecule of dimedone (2), affording Michael intermediate M1. In the meantime, the in situ generated $\mathrm{NH}_{3}$ from ammonium acetate (4) reacts with ethyl acetoacetate (3) to yield enamine E1. Then, a nucleophilic attack of E1 to the Michael intermediate M1, followed by dehydration of intermediate 6 generates enaminone 7, which tautomerizes to give keto tautomer 8 . A retro-aldol-type reaction of $\mathbf{8}$ produces aza-triene $\mathbf{9}$, which then proceeds through sixelectron thermal cyclization to give, after tautomerization of imine 10, polyhydroquinoline 5a. The second pathway, previously proposed, ${ }^{17 f, 18,20 a, 21 b, 21 k}$ involves Knoevenagel condensation of ethyl acetoacetate (3) and aldehyde (1a) to give Knoevenagel intermediate K2. Then, the Michael addition of intermediates $\mathbf{K} \mathbf{2}$ and $\mathbf{E} 2$ generates intermediate 11, which could tautomerize to give intermediate 12. An intramolecular nucleophilic attack by the amino group on the carbonyl group of $\mathbf{1 2}$ produces intermediate 13, which dehydrates to generate polyhydroquinoline $\mathbf{5 a}$.

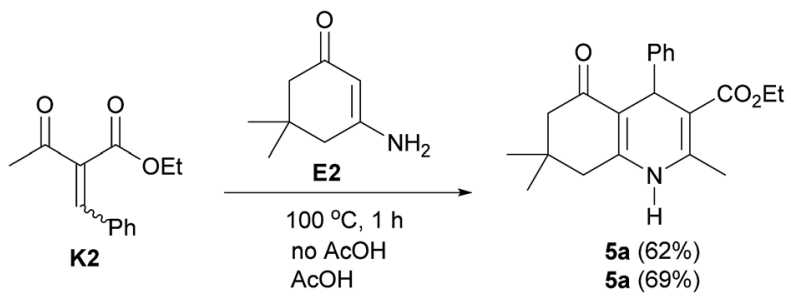

Scheme 5 Reaction of Knoevenagel adduct K2 and enamine E2. 

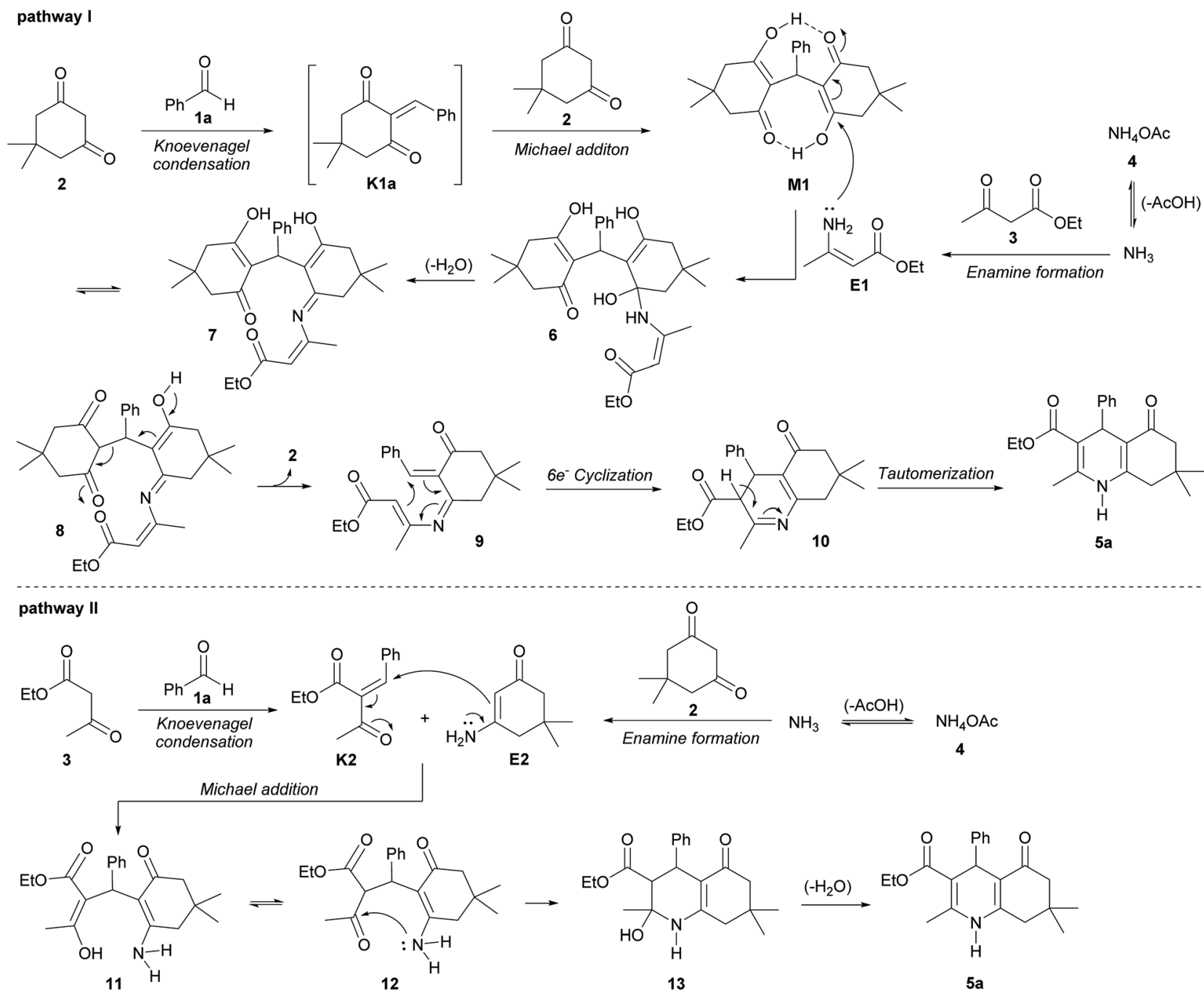

Scheme 6 Possible mechanistic pathways for the synthesis of polyhydroquinolines.

\section{Experimental}

\section{General procedure for synthesis of polyhydroquinolines}

The reaction mixture of selected aromatic aldehydes $(1,1 \mathrm{mmol}$, 1 equiv.), dimedone (2, $140.2 \mathrm{mg}, 1 \mathrm{mmol}, 1$ equiv.), ethyl acetoacetate $(3,130 \mu \mathrm{L}, 1 \mathrm{mmol}, 1$ equiv.) and ammonium acetate (4, $115.6 \mathrm{mg}, 1.5 \mathrm{mmol}, 1.5$ equiv.) was heated with stirring in a seal tube at $100^{\circ} \mathrm{C}$. After 5 min or indicated time in Table 2, the reaction mixture was cooled to room temperature and cold water $(1 \mathrm{~mL})$ was added. Then the reaction mixture was kept in ice bath for $5 \mathrm{~min}$ to obtain a solid. The resulting solid was filtered and recrystallized from ethanol or purified by silica gel column chromatography (EtOAc-hexane) to give polyhydroquinolines $\mathbf{5}$.

Ethyl 4-(3,5-dibromophenyl)-2,7,7-trimethyl-5-oxo-1,4,5,6,7,8hexahydroquinoline-3-carboxylate $(5 n)$

White solid; $R_{\mathrm{f}}=0.43$ (50\% EtOAc-hexane); $\mathrm{mp} 253-254{ }^{\circ} \mathrm{C} ;{ }^{1} \mathrm{H}$ NMR (400 MHz, CDCl $) \delta 0.96(\mathrm{~s}, 3 \mathrm{H}), 1.07(\mathrm{~s}, 3 \mathrm{H}), 1.20(\mathrm{t}, J=$ $7.1 \mathrm{~Hz}, 3 \mathrm{H}), 2.19-2.33(\mathrm{~m}, 4 \mathrm{H}), 2.37(\mathrm{~s}, 3 \mathrm{H}), 4.06(\mathrm{q}, J=7.2 \mathrm{~Hz}$, 2H), 4.96 (s, 1H), 6.37 (br s, 1H), 7.34 (s, 2H), $7.38(\mathrm{~s}, 1 \mathrm{H}) ;{ }^{13} \mathrm{C}$
NMR (100 MHz, $\left.\mathrm{CDCl}_{3}\right) \delta 14.39,19.71,27.46,29.50,33.03,36.95$, 41.26 , 50.51, 60.33, 105.63, 111.19, 122.59, 130.35, 131.94, 144.29, 150.83, 166.99, 195.46; HRMS calcd for $\mathrm{C}_{21} \mathrm{H}_{24} \mathrm{Br}_{2} \mathrm{NO}_{3}$ $(\mathrm{M}+\mathrm{H})^{+}$498.0102, found 498.0120.

\section{Ethyl 4-(2-hydroxy-5-nitrophenyl)-2,7,7-trimethyl-5-oxo-} 1,4,5,6,7,8-hexahydroquinoline-3-carboxylate (5o)

White solid; $R_{\mathrm{f}}=0.43$ (50\% EtOAc-hexane); $\operatorname{mp} 229-230{ }^{\circ} \mathrm{C} ;{ }^{1} \mathrm{H}$ NMR (400 MHz, $\left.\mathrm{CDCl}_{3}\right) \delta 0.89(\mathrm{~s}, 3 \mathrm{H}), 1.03(\mathrm{t}, J=7.1 \mathrm{~Hz}, 3 \mathrm{H})$, 1.09 (s, 3H), 2.24-2.36 (m, 4H), $2.52(\mathrm{~s}, 3 \mathrm{H}), 3.97$ (q, $J=7.1 \mathrm{~Hz}$, 2H), 5.08 (s, 1H), 6.15 (br s, 1H), 6.93 (d, $J=8.9 \mathrm{~Hz}, 1 \mathrm{H}), 7.82$ (s, 1H), $7.95(\mathrm{~d}, J=8.9 \mathrm{~Hz}, 1 \mathrm{H}), 10.40(\mathrm{~s}, 1 \mathrm{H}) ;{ }^{13} \mathrm{C} \mathrm{NMR}$ $\left(100 \mathrm{MHz}, \mathrm{CDCl}_{3}\right) \delta 13.89,19.43,27.25,28.97,30.31,32.79$, $41.36,49.78,60.32,105.71,110.64,118.50,124.26,124.66$, 134.47, 141.40, 144.52, 151.30, 160.19, 166.27, 198.53; HRMS calcd for $\mathrm{C}_{21} \mathrm{H}_{25} \mathrm{~N}_{2} \mathrm{O}_{6}(\mathrm{M}+\mathrm{H})^{+}$401.1713, found 401.1713.

\section{Conclusion}

A novel, simple and effective method for the catalyst- and solvent-free multicomponent synthesis of polyhydroquinolines 
under conventional heating at $100{ }^{\circ} \mathrm{C}$ has been established. Numerous aromatic aldehydes reacted successfully with dimedone, ethyl acetoacetate and ammonium acetate to afford the desired products in good to excellent yields with short reaction times. This method is simple and environmentally friendly. Mechanistic studies lead to the discovery of an unexpected reaction toward the synthesis of polyhydroquinolines that includes a Michael adduct as a key intermediate derived from the reaction of aldehydes with dimedone.

\section{Conflicts of interest}

There are no conflicts to declare.

\section{Acknowledgements}

This work was supported by Department of Chemistry, Faculty of Science, King Mongkut's University of Technology Thonburi. W. P. is grateful to Center of Excellence for Innovation in Chemistry (PERCH-CIC), Office of the Higher Education Commission, the Ministry of Education for the financial support. We also thank Mrs Vannapa Luckanawat for assistance with GC-MS analysis.

\section{Notes and references}

1 (a) N. Edraki, A. R. Mehdipour, M. Khoshneviszadeh and R. Miri, Drug Discovery Today, 2009, 14, 1058-1066; (b) G. Tenti, E. Parada, R. León, J. Egea, S. Martínez-Revelles, A. M. Briones, V. Sridharan, M. G. López, M. T. Ramos and J. C. Menéndez, J. Med. Chem., 2014, 57, 4313-4323.

2 (a) G. P. Young, Ann. Emerg. Med., 1984, 13, 712-722; (b) M. Martín-Martínez, F. L. Pérez-Gordillo, D. Álvarez de la Rosa, Y. Rodríguez, G. Gerona-Navarro, R. González-Muñiz and M.-M. Zhou, J. Med. Chem., 2017, 60, 2629-2650.

3 D. J. Triggle, in Comprehensive Medicinal Chemistry, Pergamon Press, Oxford, 1990, vol. 3.

4 W. J. Dana, M. A. Fuller, M. P. Goldman, J. A. Golembiewski, J. P. Gonzales and J. F. Lowe, in Drug Information Handbook with International Trade Names Index, 22nd edn, Hudson, Ohio, United States, 2013.

5 P. Beagley, M. A. L. Blackie, K. Chibale, C. Clarkson, R. Meijboom, J. R. Moss, P. J. Smith and H. Su, Dalton Trans., 2003, 3046-3051.

6 (a) N. Fokialakis, P. Magiatis, I. Chinou, S. Mitaku and F. Tillequin, Chem. Pharm. Bull., 2002, 50, 413-414; (b) K. Sirisha, D. Bikshapathi, G. Achaiah and V. M. Reddy, Eur. J. Med. Chem., 2011, 46, 1564-1571.

7 P. Fossa, L. Mosti, G. Menozzi, C. Marzano, F. Baccichetti and F. Bordin, Bioorg. Med. Chem., 2002, 10, 743-751.

8 A. Ryckebusch, R. Deprez-Poulain, L. Maes, M. A. DebreuFontaine, E. Mouray, P. Grellier and C. Sergheraert, J. Med. Chem., 2003, 46, 542-557.

9 A. R. Trivedi, D. K. Dodiya, B. H. Dholariya, V. B. Kataria, V. R. Bhuva and V. H. Shah, Bioorg. Med. Chem. Lett., 2011, 21, 5181-5183.
10 (a) L. R. Morgan, B. S. Jursic, C. L. Hooper, D. M. Neumann, K. Thanagaraj and B. LeBlanc, Bioorg. Med. Chem. Lett., 2002, 12, 3407-3411; (b) S. Valente, P. Mellini, F. Spallotta, V. Carafa, A. Nebbioso, L. Polletta, I. Carnevale, S. Saladini, D. Trisciuoglio, C. Gabellini, M. Tardugno, C. Zwergel, C. Cencioni, S. Atlante, S. Moniot, C. Steegborn, R. Budriesi, M. Tafani, D. Del Bufalo, L. Altucci, C. Gaetano and A. Mai, J. Med. Chem., 2016, 59, 1471-1491. 11 (a) A. Hilgeroth, M. Wiese and A. Billich, J. Med. Chem., 1999, 42, 4729-4732; (b) A. Hilgeroth, A. Billich and H. Lilie, Eur. J. Med. Chem., 2001, 36, 367-374; (c) A. Hilgeroth, Mini-Rev. Med. Chem., 2002, 2, 235-245.

12 (a) P. N. Kalaria, S. P. Satasia and D. K. Raval, Eur. J. Med. Chem., 2014, 78, 207-216; (b) S. C. Karad, V. B. Purohit, D. K. Raval, P. N. Kalaria, J. R. Avalani, P. Thakor and V. R. Thakkar, $R S C A d v$., 2015, 5, 16000-16009.

13 D. da Costa Cabrera, S. B. Rosa, F. S. de Oliveira, M. A. G. Marinho, C. R. Montes D'Oca, D. Russowsky, A. P. Horn and M. G. Montes D'Oca, Med. Chem. Commun., 2016, 7, 2167-2176.

14 (a) D. Schade, M. Lanier, E. Willems, K. Okolotowicz, P. Bushway, C. Wahlquist, C. Gilley, M. Mercola and J. R. Cashman, J. Med. Chem., 2012, 55, 9946-9957; (b) D. Schade and A. T. Plowright, J. Med. Chem., 2015, 58, 9451-9479.

15 K. V. Sashidhara, M. Kumar, V. Khedgikar, P. Kushwaha, R. K. Modukuri, A. Kumar, J. Gautam, D. Singh, B. Sridhar and R. Trivedi, J. Med. Chem., 2013, 56, 109-122.

16 (a) A. Hantzsch, Liebigs Ann. Chem., 1882, 215, 1-82; (b) A. Saini, S. Kumar and J. S. Sandhu, J. Sci. Ind. Res., 2008, 67, 95-111; (c) P. Arumugam and P. T. Perumal, Indian J. Chem., 2008, 47B, 1084-1090.

17 (a) L.-M. Wang, J. Sheng, L. Zhang, J.-W. Han, Z.-Y. Fan, H. Tian and C.-T. Qian, Tetrahedron, 2005, 61, 1539-1543; (b) S. Ko and C.-F. Yao, Tetrahedron, 2006, 62, 7293-7299; (c) J. L. Donelson, R. A. Gibbs and S. K. De, J. Mol. Catal. A: Chem., 2006, 256, 309-311; (d) C. G. Evans and J. E. Gestwicki, Org. Lett., 2009, 11, 2957-2959; (e) M. Hong, C. Cai and W.-B. Yi, J. Fluorine Chem., 2010, 131, 111-114; ( $f$ ) O. Goli-Jolodar, F. Shirini and M. Seddighi, $R S C$ Adv. , 2016, 6, 26026-26037; $(g)$ S. D. Guggilapu, S. K. Prajapti, A. Nagarsenkar, G. Lalita, G. M. N. Vegi and B. N. Babu, New J. Chem., 2016, 40, 838-843; (h) S. Mondal, B. C. Patra and A. Bhaumik, ChemCatChem, 2017, 9, 14691475; (i) S. Karhale, C. Bhenki, G. Rashinkar and V. Helavi, New J. Chem., 2017, 41, 5133-5141; (j) I. Sehout, R. Boulcina, B. Boumoud, T. Boumoud and A. Debache, Synth. Commun., 2017, 47, 1185-1191.

18 A. Kumar and R. A. Maurya, Tetrahedron, 2007, 63, 19461952.

19 A. Kumar and R. A. Maurya, Tetrahedron Lett., 2007, 48, 3887-3890.

20 (a) M. Tajbakhsh, H. Alinezhad, M. Norouzi, S. Baghery and M. Akbari, J. Mol. Liq., 2013, 177, 44-48; (b) A. Zare, F. Abi, A. R. Moosavi-Zare, M. H. Beyzavi and M. A. Zolfigol, $J$. Mol. Liq., 2013, 178, 113-121; (c) M. A. Zolfigol, S. Baghery, A. R. Moosavi-Zare, S. M. Vahdat, H. Alinezhad and 
M. Norouzi, RSC Adv., 2014, 4, 57662-57670; (d) M. NasrEsfahani, D. Elhamifar, T. Amadeh and B. Karimi, RSC Adv., 2015, 5, 13087-13094; (e) M. Ghorbani, S. Noura, M. Oftadeh, E. gholami and M. A. Zolfigol, RSC Adv., 2015, 5, 55303-55312; $(f)$ M. Yarie, M. A. Zolfigol, Y. Bayat, A. Asgari, D. A. Alonso and A. Khoshnood, RSC Adv., 2016, 6, 82842-82853; $(g)$ S. P. Simeonov and C. A. M. Afonso, RSC Adv., 2016, 6, 5485-5490; (h) Y. Wang, X. Liu and C. Du, Org. Prep. Proced. Int., 2017, 49, 28-34.

21 (a) M. B. Gawande, V. D. B. Bonifacio, R. S. Varma, I. D. Nogueira, N. Bundaleski, C. A. A. Ghumman, O. M. N. D. Teodoro and P. S. Branco, Green Chem., 2013, 15, 1226-1231; (b) M. Nasr-Esfahani, S. J. Hoseini, M. Montazerozohori, R. Mehrabi and H. Nasrabadi, J. Mol. Catal. A: Chem., 2014, 382, 99-105; (c) B. Paplal, S. Nagaraju, P. Veerabhadraiah, K. Sujatha, S. Kanvah, B. V. Kumar and D. Kashinath, RSC Adv., 2014, 4, 5416854174; (d) Z. Zarnegar, J. Safari and Z. M. Kafroudi, New J. Chem., 2015, 39, 1445-1451; (e) A. Amoozadeh, S. Golian and S. Rahmani, $R S C A d v ., 2015$, 5, 45974-45982; (f) M. Hajjami and B. Tahmasbi, RSC Adv., 2015, 5, 5919459203; $(g)$ A. Ghorbani-Choghamarani and G. Azadi, RSC Adv., 2015, 5, 9752-9758; (h) A. Amoozadeh, S. Rahmani, M. Bitaraf, F. B. Abadi and E. Tabrizian, New J. Chem.,
2016, 40, 770-780; (i) A. Ghorbani-Choghamarani and B. Tahmasbi, New J. Chem., 2016, 40, 1205-1212; (j) M. Nikoorazm, A. Ghorbani-Choghamarani and M. Khanmoradi, RSC Adv., 2016, 6, 56549-56561; (k) M. Hajjami and F. Gholamian, RSC Adv., 2016, 6, 8795087960; (l) E. Tabrizian and A. Amoozadeh, RSC Adv., 2016, 6, 96606-96615; $(m)$ G. B. Dharma Rao, S. Nagakalyan and G. K. Prasad, RSC Adv., 2017, 7, 3611-3616.

22 A. Sarkar, S. Santra, S. K. Kundu, A. Hajra, G. V. Zyryanov, O. N. Chupakhin, V. N. Charushin and A. Majee, Green Chem., 2016, 18, 4475-4525.

23 S. Das, S. Santra, A. Roy, S. Urinda, A. Majee and A. Hajra, Green Chem. Lett. Rev., 2012, 5, 97-100.

24 R. A. Mekheimer, A. A. Hameed and K. U. Sadek, Green Chem., 2008, 10, 592-593.

25 S. Kumar, P. Sharma, K. K. Kapoor and M. S. Hundal, Tetrahedron, 2008, 64, 536-542.

26 W. H. Correa and J. L. Scott, Green Chem., 2001, 3, 296-301. 27 (a) G. Rothenberg, A. P. Downie, C. L. Raston and J. L. Scott, J. Am. Chem. Soc., 2001, 123, 8701-8708; (b) G. W. V. Cave, C. L. Raston and J. L. Scott, Chem. Commun., 2001, 21592169.

28 T.-W. Chung, B. D. Narhe, C.-C. Lin and C.-M. Sun, Org. Lett., 2015, 17, 5368-5371. 